УАK 94(470+571)"17/1917"

ББК 63.3(2) 5

DOI 10.22394/1682-2358-2018-1-130-135

S.M. Frolova, Doctor of Sciences (Philosophy), Professor of the Philosophy of Culture and Cultural Studies Department, Saratov State University named after N.G. Chernyshevsky

\section{TRANSFORMATION OF THE EVERYDAY WAY OF LIFE \\ IN THE \\ REVOLUTIONARY ERA OF THE EARLY XX CENTURY}

The influence of the revolutionary upheaval of the early twentieth century on the changes in everyday norms of the joint being of people is examined. It is noted that as a result of the arrival of the new government, there have been changes in the housing policy, family relations, the position of women. The conclusion is drawn that the modification of the political structure of the state contributes to changes in the everyday way of life, influences the behavior patterns, moral and ethical aspects of joint life activity.

Key words and word-combinations: everyday life, daily graft, family, way of everyday life, family relations.
C.M. Фролова, доктор философских наук, профессор кафедрь философии культури и культурологии Саратовского начионального исследовательского государственного университета имени Н.Г. Черньпиевского (email: frolovasvetla777@ yandex.ru)

\section{ТРАНСФОРМАЦИЯ ПОВСЕАНЕВНОГО УКАААА БЫТИЯ \\ В РЕВОАЮЦИОННУЮ ЭПОХУ НАЧААА ХХ ВЕКА}

\begin{abstract}
Аннотация. Рассматривается влияние революционного переворота в начале XX в. на изменение повседневных норм совместного бытия людей. Отмечается, что в результате прихода новой власти произошли изменения в жилищной политике, семейных отношениях, в положении женщины. Делается вывод о том, что модификация политического устройства государства способствует переменам в повседневном укладе бытия, воздействует на модели поведения, моральные, этические аспекты совместного бытия.

Ключевые слова и словосочетания: повседневность, быт, семья, уклад каждодневного бытия, семейные отношения.
\end{abstract}

собенность Аюбого общества обусловмена стилем поведения индивидов, закрепменного не в официальных нормативных актах, а в нормах обыденной жкизни человека, выражающих предпочтения рядовых членов общества и обозначающих приоритетность основных социально-культурных, политических, нормативных, морацьных, нравственных принципов бытия этого соџиума. 
Модификация политического устройства государства, как правило, нарушает стабильно-устойчивую систему каждодневного бытия, преобразуя его бытовую сферу под идейно-политические установки. Несомненно, быт русского народа подвергался изменениям в различные периоды исторического развития, но наиболее кардинальными переменами, существенно трансформировавших установленные традиции и преобразовавших бытовые и духовные основы бытия (обойдем переустройство быта, вызванное петровскими реформами) можно считать революџионные преобразования начала XX в.

В исследовании повседневности не случайно уделяется повышенное внимание домашнему быту, поскольку именно бытовая среда обусловливает своеобразие внутреннего мира человека, его организационные установки, преАставление о вещах, образцы поведения, которые формируют особенности повседневного уклада бытия индивида и общества в целом. Повседневный уклад бытия - образ жкизни - сложно поддается изменению и оказывает симьнейшее влияние на все стороны жизни человека. Вероятно, поэтому в повседневном укладе послереволющионного общества исследователи не видят особых перемен. А.П. Овчинников подчеркивает, что «из всех сфер общественной жизни именно бытовая сфера подверглась... наименьшим переменам» [1, с. 35]. Полагаем, что с этим утверждением можно согласиться мишь частично. Не будем проводить парамлели образа жизни дворянства «до» и «после», поскольку изменения в их жизни с приходом к власти большевиков очевидны. Попробуем проанализировать перемены, точнее, последствия преобразования быта в среде «победившего класса».

Сложно подвергнуть сомнению, что основополагающим началом в организаџии быта человека явмяется жилище, дом. В своем исследовании А. Шютџ не случайно называет Аом «исходной точкой» или «нулевой точкой системы координат, которую мы приписываем миру, чтобы сориентироваться в нем» [2, с. 209]. Согласно М. Маклюэну, изменение формы внутреннего жилищного пространства свидетельствует о «новом мировоззрении» и изменении быта, что впоследствии вносит изменения в деятельность субъекта, «переупорядочивает образцы человеческой ассоџиации и общности» [3, с. 141]. После Октября 1917 г. жилищная политика новой власти была определена не только идеологическими факторами, но и нехваткой жилья. В.И. Аенин, размышляя о перевоспитании приверженцев пережитков прошиого, пишет: «Пролетарскому государству надо принудительно вселить крайне нуждающуюся семью в квартиру богатого человека. Наш отряА рабочей милищии $<\ldots .>$ является в квартиру богатого, осматривает ее, находит 5 комнат на двоих мужчин и двух женщин. - «Вы потеснитесь, граждане, в двух комнатах на эту зиму, а две комнаты приготовьте дмя посемения в них двух семей из подвала. На время, пока мы при помощи инженеров (вы, кажется, инженер?) не построим хороших квартир для всех, вам обязательно потесниться. Ваш телефон будет служить на 10 семей. Это сэкономит часов 100 работы, беготни по мавчонкам и т.п...» [4, с. 314]. Это и послужило началом изменения условий проживания граждан в период «первой фазы коммунистического общества», заверше- 
ние которой (имеется в виду расселение коммунальных квартир и получение отдельной жилплощади) потомки первых жителей коммуналок с трепетом ожидают и в наши Ани.

Понятие «коммунальные квартиры» появилось задолго до октябрьского переворота, но масштабное их применение на практике в условиях XX в. было свойственно только России. Совместное проживание в Аомах-коммунах, или «коммунах-общежитиях» (по Н.Г. Чернышевскому), трактовалось большевиками как «новая модель человеческих взаимоотношений» [5, с. 117] и преАполагало не только изменение укцада повседневного бытия, но и моральную перестройку гражАан нового государства. Понятно, что выбранный способ обеспечения жкилой площадью, кроме неудобства и неудовметворенности новыми условиями быта, ничего не вызывац. Если к этому Аобавить постоянные конфликты на общих кухнях, очереди в места общего пользования, принуАительное существование мюдей с разными соџиальными и идеологическими взглядами, низкий уровень жизни, то обстоятельства проживания в новых жкицищных условиях буАут вполне ясны.

Когда большевики в начале 1920-х годов начали расселять рабочих в порядке «революџионного эксперимента в повседневной жизни» [6, с. 162] в «барские» Аома, те нередко отказывались от новой жилплощади, так как, во-первых, эти огромные жилища нечем было отапливать, во-вторых, далеко было добираться до фабричных окраин из-за отсутствия транспорта. К тому же рабочие не понимали смысла такого переселения, они были не готовы к нему психологически и «испытывали дискомфорт в новой обстановке»; городская квартира «отличалась от устройства маленького домика на окраине, где были и погреб, и подвац, и колодец во дворе. Отсутствие этих привычных

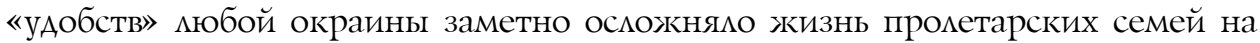
новом месте» [7, с. 26], цишало их привычных устоев. В результате оказалось что «...у многих квартиры залиты нечистотами. Водопроводы и уборные не Аействуют. Аیя последних отводятся пустующие комнаты. За недостатком Аров сжкигается последняя мебель, срываются Авери, разламываются потолки» [6, с. 27]. Кроме того, беспиатное и «ничейное», особенно в отношении жицья, которое всегда ассоџиировалось в сознании человека как цичная защита от внешнего и постороннего, не могло рассматриваться как устойчивая величина повседневной жизни, поэтому была подвержена разрушениям.

Катастрофическая нехватка средств дия поддержкания в надлежащем состоянии экспроприированных зданий вема к их запустению; непрофессиональная перепланировка бывших апартаментов и несоответствующее санитарным нормам их использование негативно сказались на состоянии практически всех строений, отАанных под жилищный фонА. Исследователями отмечается, что «в проџессе национацизаџии многое от неразумения и некультурности за ценности не принималось, растаскивалось, расхищалось и уничтожкалось... В барских домах устраивались кцубы, школы, но эти постройки быстро ветшали и разрушались [8], что привемо к разрушению исторических памятников архитектуры. Как известно, не построенное своими руками не ценится, а если здание находится в колиективном пользовании, 
то каждый считал возможным не заботиться о разумной его эксплуатации. В этом - основа разрушения укмада бытия, поскольку нарушаются традиџионно-привычные правика повседневной жизни, базирующиеся на бережном отношении к тому, чем вмадеешь сам и что находится в собственности других. Тем самым были трансформированы важнейшие дмя русского человека организационные начала, заложенные крестьянской общиной способствовавшей накоплению богатейшего опыта принятия совместных решений, и семейными традициями.

Начало разрушению патриархальных представлений о семье и семейных традиџиях было положено утопическим убеждением большевиков об отмирании семьи в недалеком будущем, их верой в то, что на смену устаревшему институту семьи в скором времени приАут Аругие, заменяющие ее институщиональные формы. Новая власть внесла изменение в само понимание института брака, теперь он стал трактоваться как равноправный союз двух товарищей, в котором женщина сохраняет экономическую, духовную, моральную и сексуальную независимость. Принщип «полового миберализма», опредемяющий право независимого "самоопределения» закрепияся в модели новой морали, основы которой были заложены А. Комлонтай, имя которой также связывают с теорией «стакана воды» - удовметворение сексуальной потребности без каких-либо «условностей».

Впоследствии граниџы гендерного порядка были тщательно отредактированы, была проведена серьезная работа над моральным обликом советского гражданина в плане исправления «буржуазных взглядов» на вопросы межмичностных отношений, что обусловило возврат (конечно, с четко обозначенным идеологическим подтекстом) к патриархально-традиционным нормам половой морали. Отметим, что произошедшее в первые годы советской власти юридическое раскрепошение женщины и распространение свободного брачного союза повлекли заметные изменения в укладе семейной жизни, что, возможно, не ограничивалось только политикой новой власти, а явцялось требованием экономического и исторического развития, обусловившим необходимость активного вовлечения женщин в сферу наемного труда и общественной жизни.

Вкмючение женщин в общественную трудовую деятельность способствовало трансформаџии ролевых стереотипов женщины, занимавшейся до револющионных преобразований преимущественно домашним хозяйством; теперь она могла (а в некоторых случаях вынуждена) идти работать. Совершенствование профессиональных навыков «слабой половины» благоприятно сказывалось на уровне ее заработной платы, что не только существенно пополняло семейный бюджет, но способствовало перераспредемению ролей и изменению статусных позищий внутри семьи.

Экономическая независимость в отношениях межАу супругами в этот период быма обусловлена не только борьбой за права женщин, но и нехваткой рабочих рук. Первая мировая война, а впоследствии и Гражданская война сократици численность мужского населения, что вызвало рост числа неполных семей. Но даже при полном (в традиционном понимании) составе 
семей женщина стала активно вовлекаться в проџесс «строительства нового общества» .

Исследователи отмечают: «Середина 20-х годов характеризуется момкой традиционно-бытового уклада, резким ослаблением влияния церкви, что было особенно характерным дмя рабочей семьи. Перестали соблюдаться посты, участились случаи гражданских обрядов при рождении детей. Типичным явмением были поиски новых бытовых и обрядовых форм: стали устраиваться комсомольские свадьбы, октябрины (праздник по поводу рождения ребенка). ОАнако в целом семейный быт бым еще очень противоречив» [9] и во многом институт церковного брака и традиционный уклаА семьи сохранялись.

На наш взгляА, разложению вековых семейных устоев способствоваци одобряемые и провоџируемые властными структурами разделение на «бемых» и «красных», отказы детей от своих родителей, «не соответствующих» требованиям советского общества по классовому признаку. Такое разрушение «брачно-семейного единства» способствовало наибольшей трансформации существующих прежде установок кажАодневного со-бытия мюдей [10, с. 185] . Тем не менее, несмотря на существенные изменения, семья оставацась и попрежннему остается главной опорой современного человека, помогающей в преодолении сложных онтологических ситуаций. Вероятно, в «условиях социальной нестабильности упрощение браков и разводов и отмена официальной

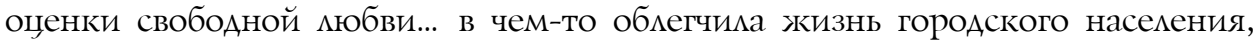
особенно молодежи, позволяя приспосабливаться к непростым условиям существования» $[11$, с. 4], но такая модификация межличностных отношений, как позже выясницось, была не нужна ни простому обывателю, ни новой вмасти, ни обшеству в цемом.

Итак, нововведения большевиков так и не смогли существенно изменить в кучшую сторону жизнь простого обывателя: семьи, переселенные в барские усадьбы, не обрели желаемого благополучия; женщины, вовлеченные в активную трудовую деятельность, получали еще большую нагрузку, так как вынуждены были совмещать работу на производстве с повседневным ведением домашнего хозяйства и воспитанием детей. Но политика новой власти, уравнявшей в правах женщин и мужчин, обеспечившей всеобщую грамотность, а также бесплатные образование и медицину, оказала значительное вмияние на развитие общества, и не только российского. Так, российский мауреат Нобелевской премии академик Ж. Алферов в беседе с представитемем популярной в России газеты «Аргументы и факты» вспоминает бесеАу с отцом своего Аруга профессора Н. Холоньяка, заметившего, что в начале

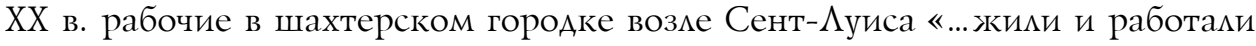
в ужасных условиях. Но после того, как русские рабочие устроили революцию, наши буржуа испугались и изменили свою социальную политику...» [12, с. 3]. Аелается заключение о том, что благодаря событиям Октября 1917 г. положение американских рабочих резко улучшилось, чего не произошио в положении рабочих в России.

Итак, укмад кажАодневного бытия, изменившись в новых условиях, вопреки прогнозам не стал кардинально новым. Многие традиции были сохранены 
или встроены в требуемые практики новой власти, некоторые «старые» формы укцада в завуацированной форме присутствовали в жкизни и до настоящего времени существуют в бытии простого обывателя как неотьемлемая его составцяющая.

\section{Библиографический список}

1. Овчинников А.П. Быт и политика: советское государство и революционная перестройка быта в 20-е гг. ХХ века (к проблемам истории государственного управления) // Вестник СамГУ. 2007. № 3 (53). C. 34-42.

2. Шюти А. Смысловая структура повседневного мира: очерки по феноменологической социологии. М., 2003.

3. Маклюэн М. Понимание Медиа: Внешние расширения человека. М., 2011.

4. Ленин В.И. Удержат ли большевики государственную власть // Полн. соб. соч. Т. 34. URL:http://leninism.su/works/73-tom-34/1702-uderzhat-li-bolsheviki-gosuda\%01 tvennuyu-vlast. html

5. Орлов И.Б. Советская повседневность: исторический и социологический аспекты становления. М., 2010.

6. Лебина Н.Б., Чистиков А.Н. Обыватель и реформы: Картины повседневной жизни горожан в годы нэпа и хрущевского десятилетия. СПб., 2003.

7. Бойм С. Общие места: мифология повседневной жизни. М., 2002.

8. Влияние Октябрьской революции на дальнейшую судьбу русской культуры. URL: https:// megalektsii.ru/s2622t1.html

9. Изменение семейных отношений у русских после Великой Октябрьской революции. URL:http://lib7.com/cccp/493-semeinue-otnoshenija-rys.html

10. Фролова С.М. Идея соборности и ее кризис в период советской действительности // Известия Саратовского университета. Новая сер.: Философия. Психология. Педагогика. 2017. Вып. 2. С. 183-188.

11. Сотникова С.A. Семья и брак в период Гражданской войны в России в 1917-1922 годы: социальная специфика и ментальность // Сервис plus. 2009. № 4. C. 3-7.

12. Писаренко Д. Как сделать науку нужной? Интервью с академиком Ж. Алферовым // Аргументы и факты. 2017. № 46. 